\title{
Antimicrobial efficacy of extracts from Alpinia purpurata (Vieill.) K.Schum. against human pathogenic bacteria and fungi
}

\author{
K.P. Kochuthressia ${ }^{1}$, S.John Britto ${ }^{1^{*}}$, M.O.Jaseentha ${ }^{1}$,L. Joelri Michael Raj $^{1}$, and \\ S.R.Senthilkumar'2. \\ ${ }^{1}$ The Rapinat Herbarium and Center for Molecular Systematics, St. Joseph's College, \\ Tiruchirappalli - 620 002, South India. \\ ${ }^{2}$ Department of Plant Biology and Plant Biotechnology, St. Joseph's College, \\ Tiruchirappalli - 620 002, South India
}

\begin{abstract}
The antimicrobial activity of three solvent extracts (ethanol, petroleum ether \& chloroform) of three different plant parts of Alpinia purpurata (leaves, roots and rhizomes) was studied in vitro against six reference strains of bacteria and four pathogenic fungi using disc diffusion assay. Ethanolic extracts of rhizomes showed a wide spectrum of activity against all tested bacteria, but no notable activity against any fungi except Candida albicans. Highest inhibition zone of (14.4 \pm $0.4 \mathrm{~mm}$ ) was recorded for the ethanolic extracts of rhizomes against Enterobacter aerogens. Petroleum ether and chloroform extracts did not show any highlighting results. The antimicrobial potential of rhizomes of $A$. purpurata is well substantiated than any other parts tested.
\end{abstract}

Keywords: Leaves, roots, rhizomes; organic extracts; antimicrobial activity; Alpinia purpurata; disc diffusion assay.

\section{INTRODUCTION:}

Medicinal plants have been used to cure disease since antiquity. Plants still constitute one of the major source of drugs in modern as well as traditional medicine throughout the world (Suri et al.,1992). Plants belonging to Zingiberaceae (Ginger family) are known for a number of medicinal properties (Basu, 2002; Kumar et al., 2006; Prajapati et al., 2005).A spectrum of essential oils are present in the members of Zingiberacae (Ibrahim and Zakaria 1987). Rhizome exract of some members of the medicinal Zingiberales are widely used in dietary intake as well as in traditional systems of medicine (Ibrahim et al., 2007). Alpinia is the largest genus in ginger family in whch Alpinia purpurata (Vieill.) K .Schum. is a very popular garden plant in India (Sabu, 2006). Rhizome has sharp odour, improves appetite, taste and voice. It is also used for head-ache, rheumatism,sore throat and renal disease (Prajapathi et al.,2003). Phytochemical studies on A.purpurata revealed that it possess flavonoids, rutin, kaempferol-3-rutinoside and kaempferol -3-oliucronide (Victorio et al., 2009). One of the major biological properties of flavonoids is their antimicrobial activity and their main role in plants is to act as protective compounds against disease caused caused by microorganism such as fungi bacteria and viruses (Wang et al, 1989). To dertermine the potential medicinal use of plants it is important to screen them for activity against a wide range of pathogenic bacteria (Fazilatun et al., 2004). Although extensive research had been done with most Alpinia species including antimicrobial work (Pant,1999; Janssen and Scheffer 1985; Morita and Itokawa 1988; Haraguchi et al.,1996; Miyazawa and Hashimoto 2002; Ray and Majumdar 1975; Ray and Majumdar 1976; Prudent et al.,1993; Lima et al.,1993; De pooter et al.,1995) little or no work in terms of antimicrobial activities have been performed in A.purpurata. The objective of the present study is to assess the antimicrobial activities of extracts obtained from leaves, roots and rhizomes of $A$. purpurata using three different solvents ethanol, petroleum ether and chloroform.

\section{MATERIALS AND METHODS}

\section{A. Purpurata}

Plant Source: $A$. pupurata plants were collected from Carmel College, Botanical garden Mala, Trichur Dt., Kerala. They were identified at The Rapinat Herbarium, St. Joseph's College (Autonomous) Tiruchirapalli, S. India and was grown in green house of Rapinat Herbarium, Tiruchirappalli and a voucher specimen was also deposited. 
Extract Preparation: 50 gms of dried powdered materials of leaves, rhizomes and roots were soaked separately in $300 \mathrm{ml}$ of each of the solvent viz. Ethanol, Petroleum ether and Chloroform, in a soxhlet apparatus for 72 hour at $31^{\circ} \mathrm{C}$ until complete exhaustion of the material. Each mixture was stirred at every 24 hour using a sterile glass rod. At the end of 72 hours, each extract was passed through whatman No. 1 filter paper and the filtrates were concentrated in vacuum rotary evaporator in order to reduce the volume into $50 \mathrm{ml}$. The extracts were stored in labelled screw bottles and kept in refrigerator at $4^{\circ} \mathrm{C}$.

Microbial strains and Culture media: Six bacterial species: Enterobacter aerogenes MTCC \# 2990, Baccilus cereus MTCC \# 1306, Streptococcus faecalis MTCC \# 459, Staphylococcus aureus MTCC \# 3163, Salmonella typhi MTCC \# 734, Escherichia coli MTCC \# 119, and four fungal species: Aspergilllus niger MTCC \# 2612, A,.flavus MTCC \# 2813 , A.fumigatus MTCC \# 2584 and Candida albicans MTCC \# 1637 were used in this study. For bacteria, the stock cultures were subcultured in nutrient broth for incubation at $37^{\circ} \mathrm{C}$ and for fungi the stock cultures were cultured in Potato dextrose broth at $28^{\circ} \mathrm{C}$ prior to each antimicrobial testing. The $24 \mathrm{hr}$ culture was stirred with $0.9 \%$ saline to achieve $0.5 \mathrm{Mc}$ farland $\left(10^{8}\right.$ cells $/ \mathrm{ml}$ for bacteria and $10^{6}$ for fungi) (Okusa et al., 2007) .Ciproflaxin and Nystatin were used as reference antbiotics (RA) respectively for bacteria and fungi.

\section{Antimcrobial assay}

Disc diffusion assay: The discs of $6 \mathrm{~mm}$ were prepared using a what-man filter paper. 100 discs were obtained by punching and putting in vialsbottles and sterilizing in an oven at $150^{\circ} \mathrm{C}$ for $15 \mathrm{~min}$. The discs were impregnated with $10 \mu \mathrm{l}$ of concentrated crude extracts. The discs were evaporated at $37^{\circ} \mathrm{C}$ for $24 \mathrm{~h}$. Prepared discs containing the various fractions were carefully placed on the inoculated plates using a sterilized forceps in each case (Fatope and Adoum, 1993). The disc with solvent alone with which the extraction was carried out was used as negative control. The plates were then turned upside-down and incubated at $37^{\circ} \mathrm{C}$ for $24 \mathrm{~h}$ in an incubator. The results were taken by considering the zone of growth and inhibition of the organisms by the test fractions. Antimicrobial activity was evaluated by measuring the diameter of the inhibition zone (IZ) around the disc. The assay was repeated thrice and mean \pm SD was calculated (Kuete et al., 2007).

\section{RESULTS AND DISCUSSION:}

Table 1 shows the zones of inhibition $(\mathrm{mm})$ of three solvent extracts (ethanol, petroleum ether \& chloroform) of three different plant parts (leaves, roots and rhizomes). Ethanolic extracts of rhizomes showed a wide spectrum of activity against the seven tested bacteria (table 1 ). Highest inhibition zone of $(14.4 \pm 0.4 \mathrm{~mm})$ was recorded for the ethanolic extracts of rhizomes against Enterobacter aerogenes. This research finding gives a scope to further screen the chemical constituents of the extracts which will be very useful to combat the common noscominal infections caused by $E$. aerogenes (Gaston, 1988; Sanders and Sanders, 1997). Antimicrobial activity is also noted for these extracts against the common pathogenic bacteria like S.typhi (12.6 \pm 0.3$)$ Streptococcus faecalis $(12 \pm 0.2)$ Escherishia coli $(11.4 \pm 0.1)$ and Staphylococcus aureus $(10 \pm 0.2)$. Such activity is also reported for rhizome extracts of other common species of Alpinia like A.galanga( Miyazawa and Hashimoto,2002). However the these extracts had only moderate activity against the four tested fungi except ethanolic rhizome extracts which showed good activity against the dermatophyte Candida albicans. Similar result is documented for the associated species such as A.galanga which was found to inhibit activity of a wide range of Candida spp. (Haraguchi et al., 1996). Biochemcal studies on other species of Alpinia reports flavanoids as antibacterial compounds responsible for activity (Ray and Majumdar, 1976). Moreover wide range of flavanoids is extracted only using ethanol as solvent (Harboune 1998). Thus these interpretations are in congruence with our findings on ethanolic rhizome extracts of A.purpurata. Ethanolic leaf extracts showed moderate activity against bacteria. Highest record of $10.6 \pm 0.1 \mathrm{~mm}$ was against $E$. aerogenes. Both bacteria and fungi showed resistance to ethanolic root extracts. Petroleum ether and chloroform extracts did not show any singnificant results except rhizome extracts of petroleum ether which again targeted its activity against E.aerogenes $(8.1 \pm 0.3 \mathrm{~mm})$. Thus we ensure the antibacterial potential of rhizomes of $A$. purpurata where ethanol could be a prescribed solvent for extraction. It is also suggested that more research be conducted to identify and elucidate active components especially flavanoids. 
Agric. Biol. J. N. Am., 2010, 1(6): 1249-1252

Table 1: Antimicrobial efficacy of different extracts of Leaves, roots and rhizomes of Alpinia purpurata against human pathogenic bacteria and fungi.

(Zones of inhibition in $\mathrm{mm}$ )

\begin{tabular}{|c|c|c|c|c|c|c|c|c|c|c|c|}
\hline \multirow{2}{*}{ Extraction } & \multirow{2}{*}{ Parts } & \multicolumn{6}{|c|}{ Bacteria } & \multicolumn{4}{|c|}{ Fungi } \\
\hline & & $\begin{array}{c}E . \\
\text { aerogenes }\end{array}$ & B. cereus & S.faecalis & S. aureus & S.typhi & E.coli & A.niger & A.flavus & A.fumigatus & C.albicans \\
\hline \multirow{3}{*}{ Ethanol } & Leaves & $10.6 \pm 0.1$ & $7.4 \pm 0.0$ & $7.6 \pm 0.7$ & $7.9 \pm 0.3$ & $7.4 \pm 0.2$ & $8.4 \pm 0.3$ & $8.0 \pm 0.2$ & $8.4 \pm 0.1$ & $\mathrm{R}$ & $7.0 \pm 0.2$ \\
\hline & Roots & $7.7 \pm 0.2$ & $7.8 \pm 0.3$ & $\mathrm{R}$ & $\mathrm{R}$ & $\mathrm{R}$ & $\mathrm{R}$ & $\mathrm{R}$ & $\mathrm{R}$ & $\mathrm{R}$ & $\mathrm{R}$ \\
\hline & Rhizome & $14.4 \pm 0.4$ & $10.2 \pm 0.3$ & $12.0 \pm 0.2$ & $10.0 \pm 0.2$ & $12.6 \pm 0.3$ & $11.4 \pm 0.1$ & $8.8 \pm 0.2$ & $8.6 \pm 0.1$ & $9.0 \pm 0.3$ & $12.4 \pm 0.2$ \\
\hline \multirow[t]{3}{*}{ Petroleum } & Leaves & $8.2 \pm 0.3$ & $\mathrm{R}$ & $7.8 \pm 0.7$ & $7.6 \pm 0.3$ & $7.2 \pm 0.2$ & $8.6 \pm 0.1$ & $\mathrm{R}$ & $7.8 \pm 0.7$ & $\mathrm{R}$ & $8.8 \pm 0.7$ \\
\hline & Roots & $\mathrm{R}$ & $\mathrm{R}$ & $\mathrm{R}$ & $\mathrm{R}$ & $\mathrm{R}$ & $\mathrm{R}$ & $\mathrm{R}$ & $\mathrm{R}$ & $\mathrm{R}$ & $\mathrm{R}$ \\
\hline & Rhizome & $8.1 \pm 0.3$ & $\mathrm{R}$ & $8.1 \pm 0.2$ & $\mathrm{R}$ & $10.3 \pm 0.2$ & $7.0 \pm 0.2$ & $8.0 \pm 0.2$ & $\mathrm{R}$ & $7.9 \pm 0.7$ & $9.6 \pm 0.7$ \\
\hline \multirow[t]{3}{*}{ Chloroform } & Leaves & $7.8 \pm 0.7$ & $7.6 \pm 0.3$ & $\mathrm{R}$ & $\mathrm{R}$ & $7.2 \pm 0.2$ & $\mathrm{R}$ & $\mathrm{R}$ & $\mathrm{R}$ & $\mathrm{R}$ & $\mathrm{R}$ \\
\hline & Roots & $\mathrm{R}$ & $\mathrm{R}$ & $\mathrm{R}$ & $\mathrm{R}$ & $\mathrm{R}$ & $\mathrm{R}$ & $\mathrm{R}$ & $\mathrm{R}$ & $\mathrm{R}$ & $\mathrm{R}$ \\
\hline & Rhizome & 8.10 .7 & $7.4 \pm 0.3$ & $\mathrm{R}$ & $\mathrm{R}$ & $7.4 \pm 0.7$ & $\mathrm{R}$ & $\mathrm{R}$ & $7.8 \pm 0.4$ & $\mathrm{R}$ & $8.2 \pm 0.2$ \\
\hline \multirow{2}{*}{$\begin{array}{l}\text { Reference } \\
\text { Antibiotics }\end{array}$} & $\begin{array}{l}\text { Ciproflaxin } \\
\text { (control) }\end{array}$ & $20 \pm 0.1$ & $32 \pm 0.3$ & $28 \pm 0.1$ & $26 \pm 0.10$ & $30.0 \pm 0.2$ & $22 \pm 0.2$ & - & - & - & - \\
\hline & $\begin{array}{l}\text { Nystatin } \\
\text { (control) }\end{array}$ & - & - & - & - & - & - & $20 \pm 0.2$ & $24 \pm 0.3$ & $20 \pm 0.4$ & $22 \pm 0.2$ \\
\hline
\end{tabular}

Values are mean of three trials \pm standard error. $\mathrm{R}=$ resistance 


\section{REFERENCE}

Basu, S.K. (2002). Herbal medicine : concepts and perspectives In: Datta Banik, S. and Basu, S.K . (ed.). Environmental perspectives and human responses. National Service Scheme (NSS) 2000-2001, Govt.of India, S.Graphics,Kolkata ,India.3:27-44.

De Pooter, H.L., Aboutabl, E.A. and El -Shabrawy, A.O. (1995). Chemical composition and antimicrobial activity of essential oil of leaf, stem and rhizome of Alpinia speciosa (J.C. Wendl.) K.Schum. grown in Egypt. Flavour Frag. J.10(2) :63-67.

Fatope ,M.O.and Adoum, O.A. (1993). Bioactivity of some savanna plants in the brine shrimp lethality test and invitro anti-microbial assay. Int. J. pharmacog. 35(5): 334-337.

Fazilatun Nessa, Nornisah Mohamed, Zhari Ismail (2004). Antibacterial activities of leaf extracts of Blumea balsamiafera. Trop.Med. Plant. 5(1):1-3.

Gaston, M. A. (1988). Enterobacter: an emerging nosocomial pathogen. J. Hosp. Infect. 11:197-208

Haraguchi, H., Kuwata, Y., Inada, K., Shingu, K., Miyahara, K., Nagao, M. and Yagi, A. (1996). Antifunfal activity from Alpinia galanga and the competition for incorporation of unsaturated fatty acid in cell growth . Planta Med.62 (4):308-313.

Harboune, (1998). Chapman and Hall, animprint of Thomson Science,2-6 Boundary Row, London SE1 $8 \mathrm{HN}, \mathrm{UK}$.p 65

Ibrahim, H. and Zakaria, M. (1987). Essential oils from three Malaysian Zingiberaceae species. Malaysian Journal of Science. 9: 73-76.

Ibrahim, H., Khalid. N. ssand Hussin. K. (2007). Cultivated gingers of peninsular Malaya: Utilization, Profiles and Micropropagation. Garden's Bulletin Singapore 59(1\&2): 71-88.

Janssen, A.M. and Scheffer, J.J. (1985) .Acetoxychavicol acetate, an antifungal component of Alpina galangal.Planta Med.(6):507-511.

Kuete, V., Nguemeving, J. R., Beng, V. P., Azebaze, A. G. B., Etoa, F. X., Meyer, M., Bodo, B., Nkengfack, A.E. (2007). Antimicrobial activity of the Methanolic extracts and compounds from Vismis laurentii De Wild (Guttiferae). Journal of Ehtnopharmacolgy .109(3): 372-379.

Kumar, V.P., Chauhan, N.S., Padh, H. and Rajani, M. (2006). Search for antibacterial and antifungal agents from selected Indian medicinal plants. J. Ethnopharmacol.107:182-188.

Lima, E.O., Gompertz, O.F., Giesbrecht, A.M. and Paulo, M.Q. (1993). In vitro antifungal activity of essential oil obtained from officinal plants against dermatophytes. Mycoses 36(9-10):333-336.

Miyazawa, M. and Hashimoto (2002). Antimicrobial and bactericidal activities of esters of 2-endo-hydroxy-1,8cineole as new aroma chemicals. J.Agric.Food Chem.50(12):3522-3526.

Morita, H. and Itokawa, H.M. (1988). Cytotoxic and antifungal diterpenes from the seeds of Alpinia galanga. Planta Med. 54(2): 117-120.

Okusa, P.N., Penge, O., Devleeschower, M. and Duez, P. (2007). Direct and indirect antimicrobial effects and antioxidant activity of Cordia gilletii De Wild (Boraginaceae). Journal of Ethnopharmacology 112:476-481.

Pant, A.K. (1999). The chemistry, biocidal and pharmacological activity of Alpinia spicies: An overview. National seminar on drugh from Himalayan Herb: Present status \& Future Strategies, Kumaun University, Naintal.India p25.

Prajapathi, N. D., Purohit, S.S., Arun, K. S and Kumar, T. (2003). A Handbook of medicinal plants. A complete source Book. Agrobios India. p. 35.

Prajapathi, N.D., Prajapathi, T and Jaipura, S. ( 2005) .Advances in medicinal plants : Vol 1 Asian medicinal plant and health care trust, Jodhpur.

Prudent, D., Perineau, J.M., Bessiere, C., Michel, G.and Bravo, R. (1993). Chemical analysis, bacteriostatic and fungistatic properties of the essential oil of the Atoumau from Martinique Alpinia speciosa K.Schum. J.Essent.Oil Res. 5(3):255-264.

Ray, P.G. and Majumdar, S.K. (1975). New antifungal substence from Aipinia officinarum Hance.Indian J.Exp.Biol.13(4):409.

Ray, P.G. and Majumdar, S.K. (1976). Antifungal flavonoid from Aipinia officinarum Hance.Indian J.Exp.Biol.14(6):712-714.

Sabu, M. (2006). Zingiberaceae and Costaceae of South India. Indian Association for Angiosperm Taxonomy, Calicut University, India pp 68-70.

Sanders, W. E.J. and Sanders, C.C. (1997). Enterobacter spp.: pathogens poised to flourish at the turn of the century. Clin. Microbiol. Rev. 10:220 -241

Suri, R.K., Chaudhari, D.C.and Jaffer, R. (1992). Commercialy important medicinal plants from forest. J.Eco.Bot. Phytochemistry. 3(2): 129-140.

Victorio, C.P., Kuster, R.M. and Lage, C.L.S. (2009). Detection of flavonoids in Alpinia purpurata (Vieill.) K. Schum. leaves using high performance liquid chromatography. Rev. Bras. PI. Med. Botucatu. 11 (2):147-153.

Wang, Y., Hamburger, M., Gueho and Hosttemann K. (1989). Antimicrobial flavonoids from Psiadia trinervia and their methylated and acetylated derivatives.Phytochemistry.28:2323-2327. 